\title{
Inhibition of pancreatic cancer stem cells by Rauwolfia vomitoria extract
}

\author{
RUOCHEN DONG, PING CHEN and QI CHEN \\ Department of Pharmacology, Toxicology and Therapeutics, KU Integrative Medicine, \\ University of Kansas Medical Center, Kansas City, KS 66160, USA
}

Received December 13, 2017; Accepted May 25, 2018

DOI: $10.3892 /$ or.2018.6713

\begin{abstract}
The poor treatment outcomes of pancreatic cancer are linked to an enrichment of cancer stem cells (CSCs) in these tumors, which are resistant to chemotherapy and promote metastasis and tumor recurrence. The present study investigated an extract from the root of the medicinal plant Rauwolfia vomitoria (Rau) for its activity against pancreatic CSCs. In vitro tumor spheroid formation and CSC markers were tested, and in vivo tumorigenicity was evaluated in nude mice. Rau inhibited the overall proliferation of human pancreatic cancer cell lines with a 50\% inhibitory concentration $\left(\mathrm{IC}_{50}\right)$ ranging between 125 and $325 \mu \mathrm{g} / \mathrm{ml}$, and showed limited cytotoxicity towards normal epithelial cells. The pancreatic CSC population, identified using cell surface markers or a tumor spheroid formation assay, was significantly reduced, with an $\mathrm{IC}_{50}$ value of $\sim 100 \mu \mathrm{g} / \mathrm{ml}$ treatment for $48 \mathrm{~h}$ and $\sim 27 \mu \mathrm{g} / \mathrm{ml}$ for long-term tumor spheroid formation. The levels of CSC-related gene Nanog and nuclear $\beta$-catenin were decreased, suggesting suppression of the $\mathrm{Wnt} / \beta$-catenin signaling pathway. In vivo, $20 \mathrm{mg} / \mathrm{kg}$ of Rau administered five times per week by oral gavage significantly reduced the tumorigenicity of PANC-1 cells in immunocompromised mice. Taken together, these data showed that Rau preferentially inhibited pancreatic cancer stem cells. Further investigation is warranted to examine the potential of Rau as a novel treatment for pancreatic cancer.
\end{abstract}

\section{Introduction}

With an estimation of 55,440 new cases $(29,200$ in men, 26,240 in women), and a mortality rate of 44,330 (23,020 men, 21,310 women) in 2018 , pancreatic cancer remains the fourth leading cause of cancer-associated mortality in the USA,

Correspondence to: Professor Qi Chen, Department of Pharmacology, Toxicology and Therapeutics, KU Integrative Medicine, University of Kansas Medical Center, 3901 Rainbow Boulevard, Kansas City, KS 66160, USA

E-mail: qchen@kumc.edu

Key words: pancreatic cancer, Rauwolfia vomitoria, cancer stem cells, tumorigenicity, medicinal plant, natural product and is one of the most life-threatening malignancies (1). As pancreatic cancer shows high level of heterogeneity and often metastasizes early, management of pancreatic cancer has always been challenging $(2,3)$. The majority of patients with pancreatic cancer $(\sim 53 \%)$ are diagnosed at an advanced stage, for whom the 5 -year-survival rate is only $2-5 \%$, which is among the lowest of all types and stages of malignancy (4). Even in the $10 \%$ patients who are diagnosed at early stages, the 5 -year-survival rate is only $32 \%$. Gemcitabine as the first line chemotherapy provides limited benefit on the overall survival rate of patients with locally advanced and metastatic pancreatic cancer $(5,6)$. Numerous efforts have been made to improve the treatment outcome. The development of treatment regimens, including FOLFIRINOX $(7,8)$ or nab-paclitaxel plus gemcitabine (9) have led to improvement in survival and response rates, however, they significantly increase toxic side effects $(10,11)$. Novel treatment options are urgently required for pancreatic cancer.

One of the reasons for the poor treatment outcomes is that pancreatic cancer has an enriched cancer stem cell (CSC) population (6). CSCs are responsible for tumor generation (3), are resistant to current chemotherapy and radiation therapies (12), and are prone to metastasis (13). The cells survive current treatments and eventually give rise to new tumors either at the primary or metastatic sites (14-16). Depending on the microenvironment, a CSC can be characteristically quiescent, and the dormancy protects them from chemotherapeutic agents that target actively dividing cells (17). Alternately, a CSC can divide and generate daughter cells which give rise to all cell types found in a particular bulk of tumor (18), and/or generate daughter cells which do not differentiate but maintain the full potential for differentiation as the parent stem cell (selfrenewal) (17). The self-renewal ability maintains the number of CSCs within the tumor, whereas its descendent progeny constitute the bulk of the tumor. CSCs also exhibit unique features, including drug resistance and metastatic ability. If a treatment does not eliminate CSCs, the CSCs eventually promote tumor recurrence. Therefore, therapies that inhibit CSCs offers promise in eliminating the whole cancer cell population.

Herbal preparations of Rauwolfia vomitoria (Rau), a tropical shrub in the family Apocynaceae, is a traditional folk medicine in Africa used to treat a variety of conditions, including hypertension $(19,20)$, fever $(21,22)$, gastrointestinal 
diseases (23), liver diseases (24) and cancer (25). The extract as a whole mixture is widely used as a health supplement. Extracts from the root bark of this plant are enriched with $\beta$-carboline alkaloids and indole alkaloids (26). $\beta$-carboline alkaloids have been reported to have several bioactivities, including antitumor effects (27,28). In our previous study, it was reported that an extract of Rau, with its hypotensive component reserpine removed, induced pancreatic cancer cell apoptosis, and inhibited pancreatic tumor growth in mice (29). The combination of Rau and gemcitabine showed synergistic antitumor effects (29). In the present study, the activities of the same extract on inhibiting pancreatic CSCs in vitro and in vivo were investigated.

\section{Materials and methods}

Cell lines and reagents. The PANC-1, AsPC-1, HPAF-II, BxPC-3 and MiA PaCa-2 human pancreatic cancer cell lines were obtained from the American Type Culture Collection (ATCC, Manassas, VA, USA) and maintained in the laboratory. The MRC-5 immortalized human lung epithelial cell line was provided by Dr Sitta Sittampalam at the National Center for Advancing Translational Sciences, NIH (Bethesda, MD, USA), and was used as a comparison to the cancer cells. All cells were cultured at $37^{\circ} \mathrm{C}$ in $5 \% \mathrm{CO}_{2} / 95 \%$ air in recommended growth media: PANC-1 and Mia PaCa-2 in DMEM (cat no. 10-013CV; Corning, Inc., Corning, NY, USA); AsPC-1 and BxPc-3 in RPMI-1640 (cat. no. 10-040-CV; Corning, Inc.) and HPAF-II in EMEM (cat. no. 10-010-CV; Corning Inc.), containing 10\% fetal bovine serum (FBS; Sigma-Aldrich, St. Louis, MO, USA; cat. no. F0926) and 1\% antibiotics (cat. no. 30-001-C; Corning, Inc.). The Rau extract was provided by Natural Source International, Ltd. (New York, NY, USA) and was prepared in sterile phosphate-buffered saline (PBS) in $10 \mathrm{mg} / \mathrm{ml}$ stock solutions and stored at $-20^{\circ} \mathrm{C}$.

Cell viability assay. The cells were assessed for viability using a 3-(4, 5-dimethylthiazol-2-yl)-2, 5-diphenyltetrazolium bromide (MTT) assay at $48 \mathrm{~h}$ of treatment. Cells in the exponential growth phase were exposed to serial dilutions of Rau for $48 \mathrm{~h}$. The medium was then replaced with fresh media containing MTT and cells were incubated for $4 \mathrm{~h}$ at $37^{\circ} \mathrm{C}$. The colorimetric MTT assay assesses relative proliferation, based on the ability of living, but not dead cells, to reduce MTT to formazan. The cells did not reach a plateau phase during the incubation period. The $50 \%$ inhibitory concentration $\left(\mathrm{IC}_{50}\right)$ was defined as the concentration of drug that inhibited cell growth by $50 \%$ relative to the untreated control. Pilot experiments for each cell line were performed to optimize cell density and assay duration, and to center drug dilution series approximately on the $\mathrm{IC}_{50}$.

Tumor spheroid formation assay. For the PANC-1 cells, a single-cell suspension was plated into 24-well ultra-low attachment plates (Corning Inc.) at a density of 5,000 cells/well in stem cell media and incubated at $37^{\circ} \mathrm{C}$ in a humidified atmosphere of $95 \%$ air and $5 \% \mathrm{CO}_{2}$. For the MIA PaCa-2 cells, a singlecell suspension was plated into 96-well ultra-low attachment plates (Corning Inc.) at a density of 100 cells/well in stem cell media and incubated under the same conditions. The stem cell media consisted of DMEM (Corning Inc.) supplemented with 1X B27 Supplement, $20 \mathrm{ng} / \mathrm{ml}$ human basic fibroblast growth factor, $20 \mathrm{ng} / \mathrm{ml}$ epidermal growth factor, $100 \mathrm{U} / \mathrm{ml}$ penicillin/ streptomycin (Invitrogen; Thermo Fisher Scientific, Inc.) and $4 \mu \mathrm{g} / \mathrm{ml}$ heparin calcium salt (Thermo Fisher Scientific, Inc.). The PANC-1 spheroids were counted following 4 weeks of culture and the MIA PaCa-2 spheroids were counted following 2 weeks of culture under the microscope. Spheroid diameter was measured using ImageJ software v1.48 (NIH, Bethesda, MD, USA).

Flow cytometry for the detection of CSC surface markers. Rau has marked autofluorescence in two ranges of emission wavelength, at 400-600 $\mathrm{nm}$ and $800-900 \mathrm{~nm}$, overlapping the emission wavelength of several fluorescent labeling molecules. Therefore, PE-Cy7-conjugated CD24 and APC-conjugated EpCam antibodies were used as indicative markers for pancreatic CSCs $\left(\mathrm{CD} 24^{+} \mathrm{EpCam}^{+}\right)$to avoid overlapping with Rau autofluorescence. The cells were exposed to various concentrations of Rau for 24 or $48 \mathrm{~h}$. The cells were then washed with PBS three times, and resuspended in binding buffer (PBS supplemented with $0.1 \%$ bovine serum albumin (BSA; Fisher BioReagents, Waltham, MA, USA; cat. no. BP1605100) for $15 \mathrm{~min}$. PE-Cy-7-conjugated anti-CD24 antibody (dilution 1:100; cat. no. 311119; BioLegend, Inc., San Diego, CA, USA) and APC-conjugated anti-EpCam antibody (dilution 1:100; cat. no. 324207; BioLegend, Inc.) were added into the cell suspension and incubated for $15 \mathrm{~min}$ according to the manufacturer's protocol. The cells were washed in PBS three times following staining and then analyzed using a BD LSR II flow cytometer. The data were normalized to cell death, as follows: Normalized CSC population = original CSC population detected with flow cytometry $\mathrm{x} \%$ cell viability detected with the MTT assay.

Flow cytometry for sorting of side population from pancreatic cancer cells. Dye Cycle Violet (DCV; Invitrogen; Thermo Fisher Scientific, Inc.) was used for staining of the non-CSC population. Cells that efficiently exclude DVC from the cytoplasm are considered CSC-like population $\left(\mathrm{DCV}^{-}\right.$ cells). The MIA PaCa-2 cells were suspended at a density of $1 \times 10^{6}$ cells/ml in DEME supplemented with $10 \%$ FBS and $10 \mathrm{mM}$ HEPES. DCV $(10 \mu \mathrm{M})$ was added and incubated for $30 \mathrm{~min}$ at room temperature. The cells were then washed twice with PBS, and resuspended in DMEM supplemented with $10 \%$ FBS and $10 \mathrm{mM}$ HEPES for $1 \mathrm{~h}$. The cells were transferred to ice-cold HBSS/2\% FBS/10 mM HEPES buffer immediately prior to flow cytometric sorting. The $\mathrm{DCV}^{-}$and $\mathrm{DCV}^{+}$cells were separately collected for further analysis. Gate setting was performed using cells treated with a pump inhibitor (verapamil; $200 \mu \mathrm{M}$ ) prior to DCV staining.

SDS PAGE and western blot analysis. The cells were lysed with RIPA buffer containing protease inhibitors and phosphatase inhibitors (Sigma-Aldrich; EMD Millipore) followed by sonication for $10 \mathrm{sec}$. Either whole cell lysate or supernatant was used for further experiments, depending on the proteins of interest. The BCA method was used for protein quantification (Pierce BCA protein assay kit; Thermo Fisher Scientific, Inc.). SDS-PAGE and western blot analyses were performed 
as routine: $10 \mu \mathrm{g}$ total protein or $2 \mu \mathrm{g}$ nuclear or cytoplasmic fractions were loaded on a $10 \%$ SDS-PAGE gel, and electrophoresis was performed at $60 \mathrm{~V}$ for 35 min followed by $90 \mathrm{~V}$ for $90 \mathrm{~min}$. Proteins were transferred to PVDF membrane (cat.no.ISEQ00010; ED Millipore, Burlington, USA) overnight. Membrane was then blocked with 5\% blocking grade blocker (cat. no. 170-6404; Bio-Rad Laboratories, Inc., Hercules, CA, USA) in 1X TBS-T (Tween-20, 0.1\%) for $2 \mathrm{~h}$ at room temperature with constant shaking. Primary and secondary antibodies were from Cell Signaling Technology Inc. (Danvers, MA, USA): rabbit anti- $\beta$-catenin (dilution 1:1,000; cat. no. 9582), rabbit anti-vinculin (dilution 1:1,000; cat. no. 4650), rabbit antiHistone H3 (dilution 1:2,000; cat. no. 4499), rabbit anti-Nanog (dilution 1:2,000; cat. no. 4903), mouse anti- $\beta$-actin (dilution 1:2,000; cat. no. 3700), and goat anti-rabbit (dilution 1:5,000; cat. no. 7074) or anti-mouse (dilution 1:5,000; cat. no. 7076) IgG. Primary antibodies were incubated overnight at $4{ }^{\circ} \mathrm{C}$ and secondary antibodies were incubated for $2 \mathrm{~h}$ at room temperature. The blots were established using a chemiluminescence detection kit (Pierce ECL; cat. no. 32106) or ECL Plus Western Blotting Substrate (cat. no. 32132) which were both from Thermo Fisher Scientific, Inc.

RNA isolation, cDNA synthesis and reverse transcriptionquantitative polymerase chain reaction ( $R T-q P C R)$ analysis. Total RNA was extracted from cells or tissue samples using TRIzol reagent according to the protocol of the manufacturer (Invitrogen; Thermo Fisher Scientific, Inc.). cDNA synthesis was performed with $1 \mu \mathrm{g}$ of total RNA using an Omniscript RT kit according to the manufacturer's protocol (Qiagen, Inc., Valencia, CA, USA). cDNA was diluted 1:5 in DEPC-treated nanopure water and used for further analysis. RT-qPCR analysis was performed using a Bio-Rad iQ iCycler detection system with iQ SYBR green supermix (Bio-Rad Laboratories, Inc.). The reactions were performed in a total volume of $10 \mu \mathrm{l}$, including $5 \mu \mathrm{l}$ of $2 \mathrm{X}$ iQ SYBR Green supermix, $0.4 \mu \mathrm{l}$ of primers at $20 \mathrm{pmol} / \mu \mathrm{l}$ and $0.4 \mu \mathrm{l}$ of cDNA template. Primer sequences are as follows: BCL2L2 (F, GCGGAGTTCAC AGCTCTATAC and R, AAAAGGCCCCTACAGTTACCA); Cox-2 (F, CTGGCGCTCAGCCATACAG and R, CGCAC TTATACTGGTCAAATCCC); MMP14 (F, GGCTACAGC AATATGGCTACC and R, GATGGCCGCTGAGAGTGAC); MYC (F, TCCCTCCACTCGGAAGGAC and R, CTGGT GCATTTTCGGTTGTTG); hBim (F, TACTCCAGTGC AGTCTCCTC and R, TCCCATCTTTCCTAACACAG); hDppa4 (F, AAAAGCAAGAAGGGAGAGTGA and R, CGG AGATTGCACTGAACTGA); hEsrrb (F, TCAGAGAGCA GCCCATACCT and R, GCGTCACAAACT CCTCCTTC); hOct4 (F, GAGAATTTGTTCCTGCAGTGC and R, GTTCCC AATTCCTTCC TTAGTG); hSox2 (F, ATGGGTTCG GT GGTCAAGTC and R, GTGGATGGGATTGGTGTTCTC); hTbx3 (F, GAAGAAGAGGTGGAGGACGA and R, ATTCAG TTTCGGGGAACAAG); hTcl1 (F, GATACCGATCCTCA GACTCCA and R, GAGGGACAGAAGGGACAGAA); GAPDH (F, CCAGGTGGTCTCCTCTGACTTCAACA and R, AGGGTCTCTCTCTTCCTCTTGTGCTC). All qPCR were run according to the following thermocyclers: Initial denaturation and enzyme activation at $95^{\circ} \mathrm{C}$ for $3 \mathrm{~min}$, followed by 40 cycles of denaturing $\left(95^{\circ} \mathrm{C}\right.$ for $\left.15 \mathrm{sec}\right)$, annealing $\left(55-60^{\circ} \mathrm{C}\right.$ for $\left.30 \mathrm{sec}\right)$, and extension $\left(72^{\circ} \mathrm{C}\right.$ for $\left.30 \mathrm{sec}\right)$. Melt curve was carried out at $55-950 \mathrm{C}$ (in $0.50 \mathrm{C}$ increments) for $30 \mathrm{sec}$.

All reactions were performed in four repeats for every sample and with three independent experiments for each group. GAPDH was used as housekeeping gene for normalization. Gene expression was quantified using $\Delta \Delta \mathrm{CT}$ method and $2^{-\Delta \Delta \mathrm{Ct}}$ was used as the relative expression changes for each gene (30).

Pancreatic cancer xenograft mouse model. All animal experiments followed a protocol approved by the Institutional Animal Care and Use Committee of the University of Kansas Medical Center (Kansas City, KS, USA). Single treatment and repeated treatments were each used for the measurement of tumorigenecity. In the single treatment model, the PANC-1 pancreatic cancer cells at three densities were used for tumor inoculation $\left(2 \times 10^{4}\right.$ cells per injection, $2 \times 10^{5}$ cells per injection, or $1 \times 10^{6}$ cells per injection). The PANC-1 cells were suspended in PBS as single cell suspension and then mixed with either $200 \mathrm{mg} / \mathrm{ml}$ Rau or PBS. At each cell injection number, cells mixed with Rau were injected subcutaneously into the left flank of the mouse, and cells mixed with PBS were injected into the right flank of the same mouse. A total of 10 mice (Athymic Ncr nu/nu, female, 4-6 weeks, 15-20 g) were used for each cell density. The formation of tumors were monitored daily, and longitudinal tumor growth was measured using calipers. Mice were housed in 5 mice/cage in a sterile rodent room with $12-\mathrm{h} / 12 \mathrm{~h}$-light/dark cycle. Housing was handled by the University of Kansas Medical Center Laboratory Animal Resources following standard protocol.

In the repeated treatment model, a single cell suspension of PANC-1 cells was mixed with $200 \mathrm{mg} / \mathrm{ml} \mathrm{Rau}$, and then inoculated into 10 mice at $2 \times 10^{5}$ cells per injection, in the left and right flanks. Treatment was started the following day with oral gavage of $20 \mathrm{mg} / \mathrm{kg}$ Rau, five times per week for 3 weeks. In the control group (10 mice), the mice were inoculated with the same number of cells in PBS, and were then gavaged with an equivalent volume of saline solution. Tumor formation was monitored daily, and longitudinal tumor growth was measured using calipers.

Statistical analysis. Statistical analysis was performed using IBM SPSS statistical software, version 23 (IBM PSS, Armonk, NY, USA). Student's t-test and a log-rank test were used. $\mathrm{P}<0.05$ was considered to indicate a statistically significant difference.

\section{Results}

Inhibition of pancreatic cancer tumor spheroid formation in vitro. Five human pancreatic cancer cell lines (PANC-1, MiA PaCa-2, AsPC-1, HPAF-II and BxPC-3) and an immortalized epithelial cell line (MRC-5) were treated with various concentrations of Rau, and cell viability was detected $48 \mathrm{~h}$ later. Rau inhibited the proliferation of all five cancer cells (Fig. 1A), with $\mathrm{IC}_{50}$ values ranging between 140 and $317 \mu \mathrm{g} / \mathrm{ml}$. The non-cancerous MRC-5 epithelial cell line was less affected by Rau treatment, with a higher $\mathrm{IC}_{50}$ value of $567 \mu \mathrm{g} / \mathrm{ml}$ (Fig. 1B). These results are consistent with our previous findings that Rau inhibited the overall proliferation of pancreatic cancer cells (29). 
A

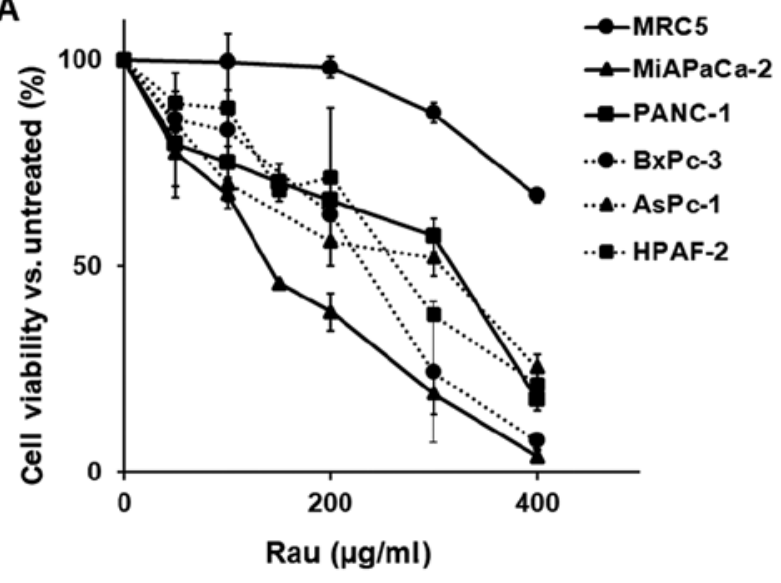

B

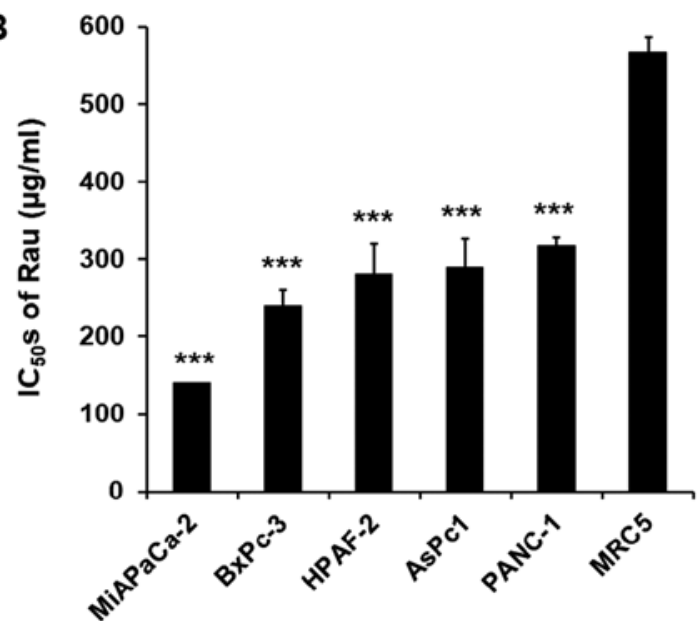

Figure 1. Inhibition of the proliferation of pancreatic cancer cells by Rau. (A) Dose-response curves. Human PANC-1, AsPC-1, HPAF-II, BxPC-3 and MiA $\mathrm{PaCa}-2$ pancreatic cancer cells were exposed to serial concentrations of Rau for $48 \mathrm{~h}$. Cell viability was detected using a 3-(4, 5-dimethylthiazol-2-yl)-2, 5-diphenyltetrazolium bromide assay. An immortalized non-cancerous MCR-5 epithelial cell line was subjected to the same treatment. (B) IC $\mathrm{C}_{50}$ values of Rau in pancreatic cancer cells and MRC-5 cells. ${ }^{* * *} \mathrm{P}<0.001$, compared with the $\mathrm{IC}_{50}$ of MRC-5 cells. All values are expressed as the mean \pm standard deviation of three independent experiments each performed in triplicate. Rau, Rauwolfia vomitoria; $\mathrm{IC}_{50}, 50 \%$ inhibitory concentration.

A

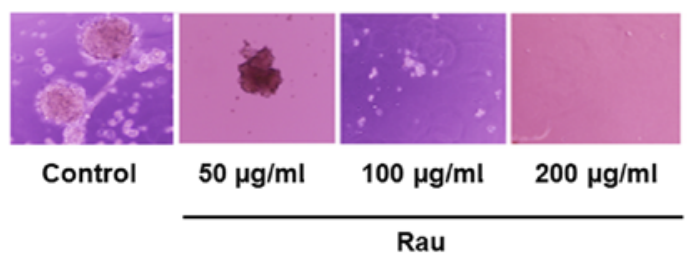

C

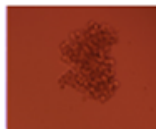

Control

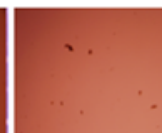

$50 \mu \mathrm{g} / \mathrm{ml}$

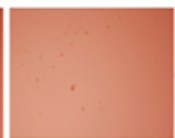

$100 \mu \mathrm{g} / \mathrm{m}$

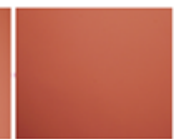

$200 \mu \mathrm{g} / \mathrm{ml}$

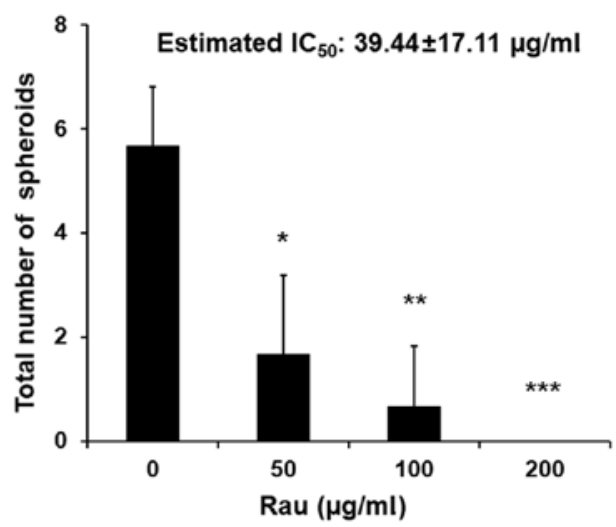

D

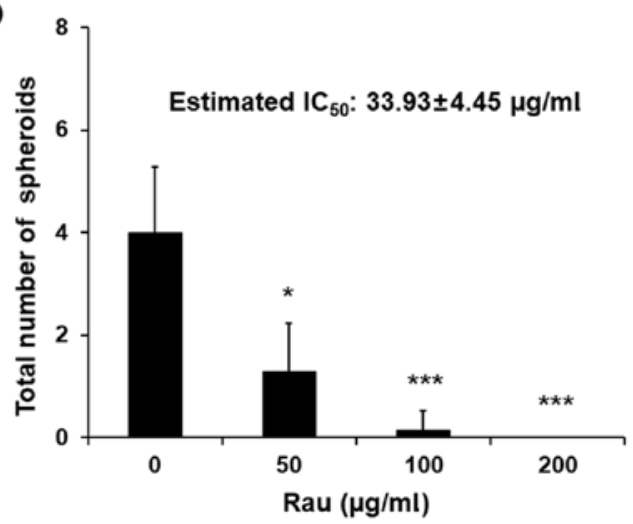

Figure 2. Inhibition of pancreatic tumor spheroids by Rau. (A) Representative images of the spheroids with and without Rau treatment (magnification, x10). A PANC-1 single-cell suspension was plated into 24-well ultra-low attachment plates at a density of 5,000 cells/well in stem cell media. Tumor spheroids were counted 4 weeks later. (B) Number of PANC-1 spheroids (mean \pm standard deviation of three independent experiments). ${ }^{*} \mathrm{P}<0.05,{ }^{* * *} \mathrm{P}<0.01$ and ${ }^{* * * *} \mathrm{P}<0.001$, compared with the untreated control. (C) Representative images of the MIA PaCa-2 spheroids with and without Rau treatment. MIA PaCa-2 single-cell suspension was plated into 96-well ultra-low attachment plates at a density of 100 cells/well in stem cell media. Tumor spheroids were counted 2 weeks later. (D) Number of MIA PaCa-2 spheroids (mean \pm standard deviation of three independent experiments). Rau, Rauwolfia vomitoria; $\mathrm{IC}_{50}, 50 \%$ inhibitory concentration.

To investigate the inhibitory effect of Rau in CSCs, a tumor spheroid formation assay was performed. The ability to form tumor spheroids is an in vitro indication of the tumorigenic capacity and self-renew ability of CSCs. When cancer cells are cultured in non-adherent, serum-free conditions, non-CSC populations die by anoikis, whereas CSCs overcome anoikis and go through division leading to the formation of tumor spheroids $(32,33)$. Single cell suspensions were treated with 

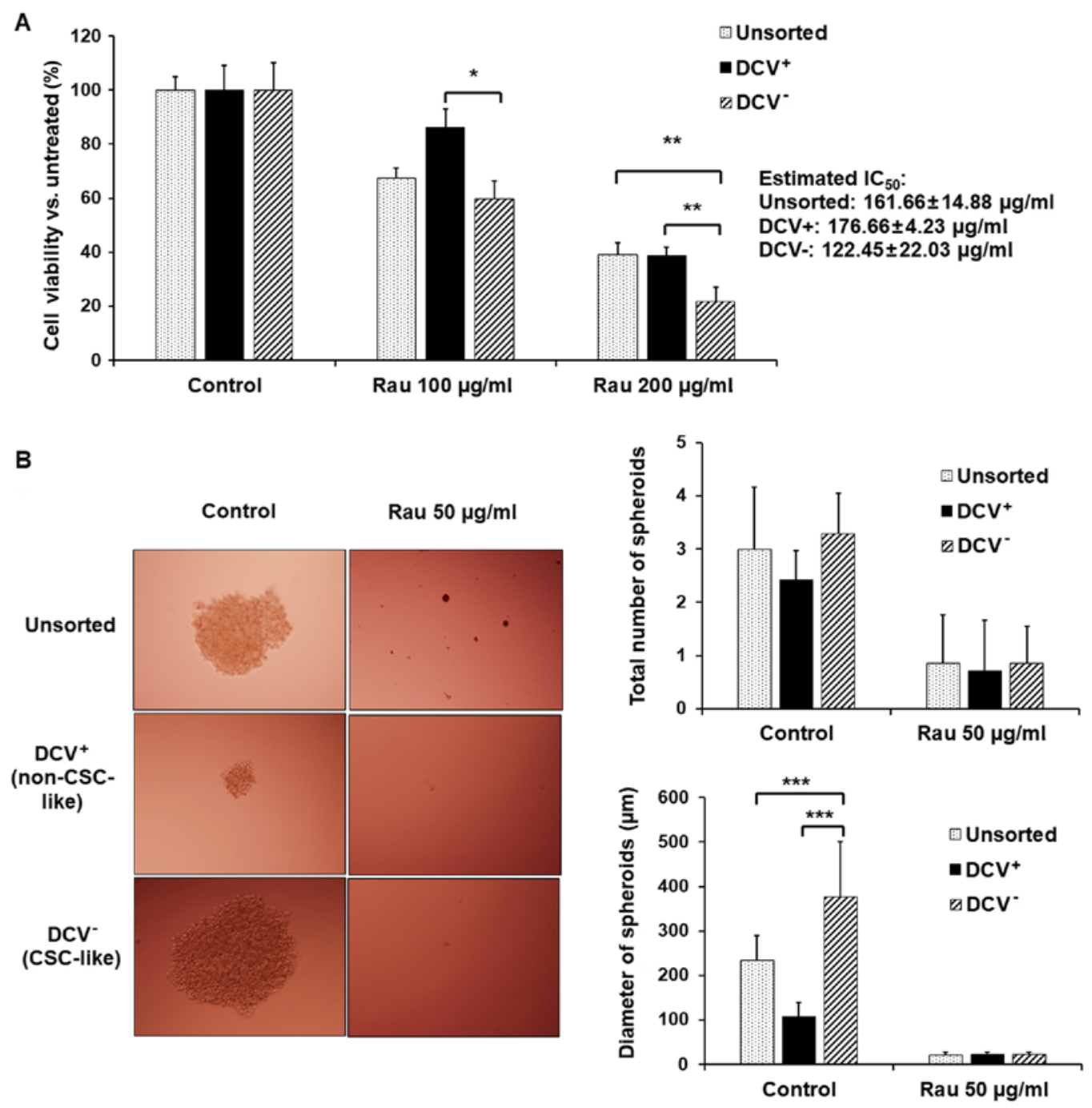

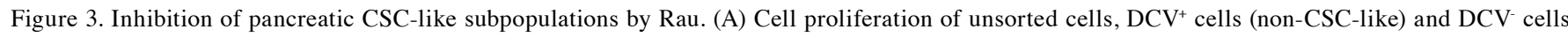
(CSC-like) with Rau treatment for $48 \mathrm{~h}$ (mean \pm standard deviation of three independent experiments). (B) Representative images of the MIA PaCa-2 spheroids from unsorted cells, $\mathrm{DCV}^{+}$cells and $\mathrm{DCV}^{-}$cells with and without Rau treatment (magnification, $\mathrm{x} 10$ ). The number and size of MIA PaCa-2 spheroids are shown in bar graph. ${ }^{*} \mathrm{P}<0.05 ;{ }^{* * *} \mathrm{P}<0.01$ and ${ }^{* * * *} \mathrm{P}<0.001$. CSC, cancer stem cell; Rau, Rauwolfia vomitoria; DCV, Dye Cycle Violet; $\mathrm{IC}_{50}, 50 \%$ inhibitory concentration.

Rau and tumor spheroids were counted 4 weeks later. Data showed that Rau significantly reduced the number of the PANC-1 tumor spheroids at the concentrations of 50 and $100 \mu \mathrm{g} / \mathrm{ml}$, and completely eliminated the tumor spheroids at $200 \mu \mathrm{g} / \mathrm{ml}$ (Fig. 2A and B). The estimated $\mathrm{IC}_{50}$ value for tumor spheroids inhibition is $39.44 \mu \mathrm{g} / \mathrm{ml}$. By contrast, the $\mathrm{IC}_{50}$ value of Rau to the bulk of PANC-1 cells was $317 \mu \mathrm{g} / \mathrm{ml}$ (Fig. 1B). The MIA PaCa-2 pancreatic cancer cells were also treated by Rau for the detection of tumor spheroids. Similar results were obtained. Rau reduced the number of the MIA PaCa-2 spheroids at $50 \mu \mathrm{g} / \mathrm{ml}$, and completely inhibited spheroid formation at $\geq 100 \mu \mathrm{g} / \mathrm{ml}$ (Fig. 2C and D). The estimated IC $_{50}$ value of $34 \mu \mathrm{g} / \mathrm{ml}$ (Fig. 2D) was lower than the $\mathrm{IC}_{50}$ value for the bulk of the MIA PaCa-2 cells (Fig. 1A).

Cells with stemness features are reported to exclude dyes as side populations $(34,35)$. In order to separate the CSC-like population, MIA $\mathrm{PaCa}-2$ cells were sorted using flow cytometry with DCV staining. The $\mathrm{DCV}^{-}$cells (CSC-like) and $\mathrm{DCV}^{+}$ (non CSC-like) cells were collected and treated with Rau. Rau inhibited the viability in all unsorted, $\mathrm{DCV}^{+}$and $\mathrm{DCV}^{-}$cells, preferentially inhibiting DCV*cells (Fig. 3A). The estimated $\mathrm{IC}_{50}$ values were $162 \mu \mathrm{g} / \mathrm{ml}$ in unsorted cells, $177 \mu \mathrm{g} / \mathrm{ml}$ in $\mathrm{DCV}^{+}$cells and $122 \mu \mathrm{g} / \mathrm{ml}$ in $\mathrm{DCV}^{-}$cells. This result suggested that Rau preferentially inhibited CSC-like cells.

Tumor spheroid formation was detected. Although cell spheroids were also formed in the $\mathrm{DCV}^{+}$cell culture, they were significantly smaller (Fig. 3B). By contrast, $\mathrm{DCV}^{-}$cells formed large spheroids, as expected. As there is currently no exclusive way to pin-point pancreatic CSCs, the formation of spheroids in $\mathrm{DCV}^{+}$cells may due to the remaining CSC-like cells in the $\mathrm{DCV}^{+}$population. However, the DCV staining and sorting provided a side population enriched with 'stemness'. Rau at $50 \mu \mathrm{g} / \mathrm{ml}$ inhibited spheroids in the $\mathrm{DCV}^{-}$and $\mathrm{DCV}^{+}$ populations (Fig. 3B), a result consistent with those in unsorted cells.

Reduction of the CSC marker-positive cell population. The effects of Rau on CSCs in a shorter time period were also examined. The PANC- 1 cells were treated with Rau for 24 or $48 \mathrm{~h}$ at concentrations of 50,100 or $200 \mu \mathrm{g} / \mathrm{ml}$. The pancreatic 
A
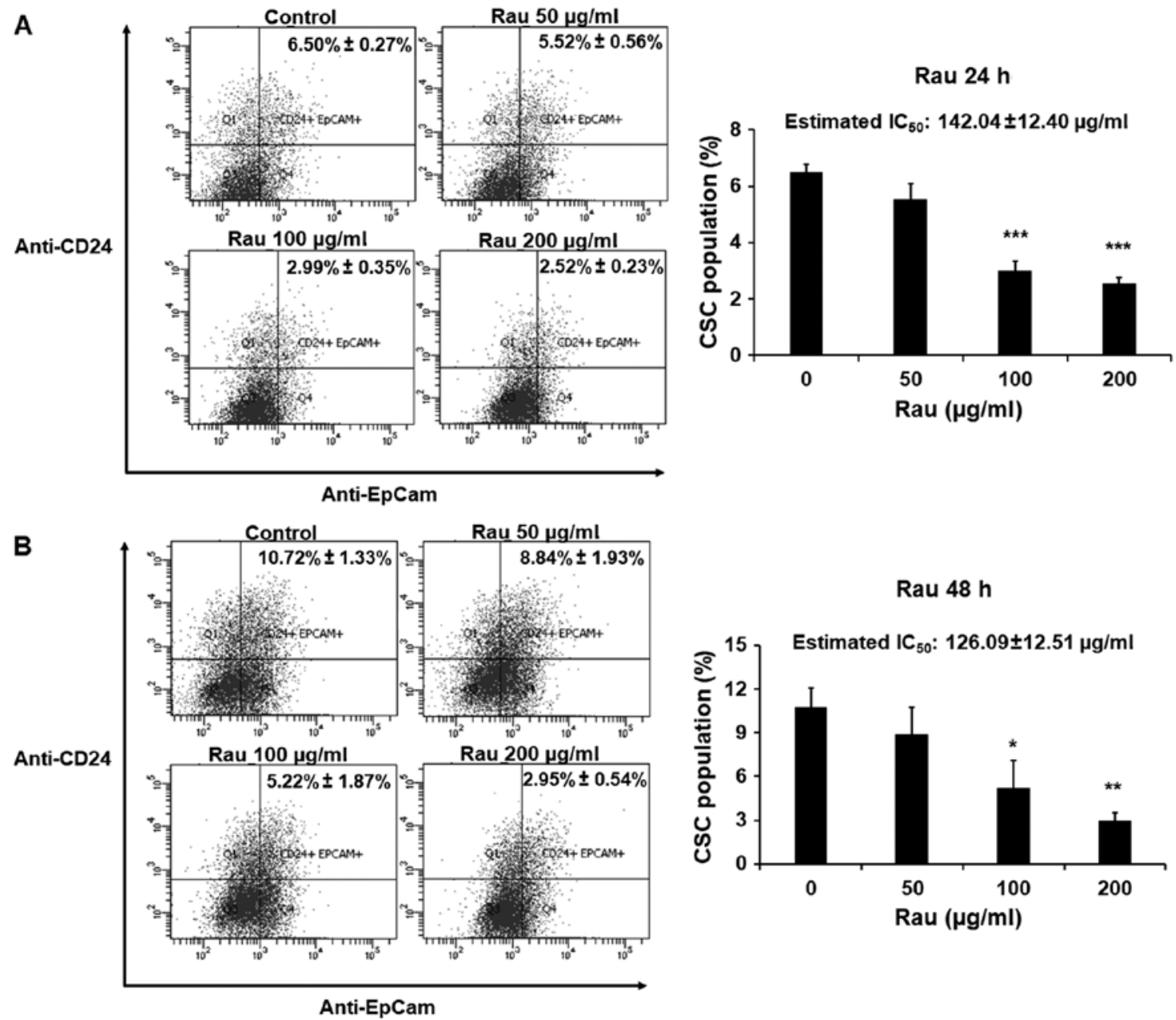

Figure 4. Inhibition of CSC populations by Rau. PANC-1 cells were treated with Rau for (A) 24 and (B) $48 \mathrm{~h}$ at the indicated concentrations. Cells were then stained with fluorescent conjugated antibodies for CD24 and EpCam, followed by flow cytometric analysis. Left panels show the EpCam (APC) and CD24 (PE) positive cells. The percentages of $\mathrm{CD} 24^{+} \mathrm{EpCam}^{+}$cells were quantified and shown in the bar graph (mean \pm standard deviation of three experiments). The data were normalized to cell death. ${ }^{*} \mathrm{P}<0.05 ;{ }^{* *} \mathrm{P}<0.01 ;{ }^{* * *} \mathrm{P}<0.001$, compared with the untreated group. CSC, cancer stem cell; Rau, Rauwolfia vomitoria; $\mathrm{IC}_{50}$, $50 \%$ inhibitory concentration.

CSC markers CD24 and EpCAM were examined by immune staining followed by flow cytometric analysis. Rau reduced the $\mathrm{CD} 24^{+} \mathrm{EpCam}^{+}$cell population following 24 and $48 \mathrm{~h}$ treatment (Fig. 4A and B). In the control groups, CD24 ${ }^{+} \mathrm{EpCam}^{+}$ cells consisted of $6.50-10.72 \%$ of the whole population. At the concentration of $200 \mu \mathrm{g} / \mathrm{ml}$, Rau significantly reduced CD24+EpCam ${ }^{+}$cells to $2.52-2.95 \%$ following 24 and $48 \mathrm{~h}$ of treatment (Fig. 4A and B). At a lower concentration of $100 \mu \mathrm{g} / \mathrm{ml}$, Rau also significantly reduced the CD24 ${ }^{+} \mathrm{EpCam}^{+}$ cells to $2.99-5.22 \%$ following 24 and $48 \mathrm{~h}$ of treatment (Fig. 4B). It was estimated that the $\mathrm{IC}_{50}$ value at 24-h treatment was $142.04 \pm 12.40 \mu \mathrm{g} / \mathrm{ml}$, and at $48 \mathrm{~h}$ treatment was $126.09 \pm 12.51 \mu \mathrm{g} / \mathrm{ml}$ (Fig. 4A and B), and these values were lower than the $\mathrm{IC}_{50}$ values for the bulk tumor cells. These data are consistent with the results above showing that Rau preferentially inhibited pancreatic CSCs.

One of the essential pathways in maintaining the selfrenewal and spheroid formation capacities of CSCs is activation of the canonical Wnt $/ \beta$-catenin signaling pathway $(18,36)$. When there is active Wnt signaling, the $\beta$-catenin degradation complex in the cytosol dissociates, and $\beta$-catenin accumulates in the nucleus and functions as a transcriptional factor to upregulate genes that promote CSC stemness, including Nanog (37). In the present study, the cytoplasmic and nuclear fractions of the PANC-1 cells were each examined for $\beta$-catenin levels with or without Rau treatment. Treatment with Rau $(100 \mu \mathrm{g} / \mathrm{ml})$ for 24 and $48 \mathrm{~h}$ reduced the levels of $\beta$-catenin in the nucleus (Fig. 5A), whereas the cytoplasmic $\beta$-catenin levels were not changed (Fig. 5A). A panel of $\beta$-catenin downstream target genes, including B-cell lymphoma 2-like 2 (BCL2L2), cyclooxygenase-2 (COX-2), matrix metalloproteinase (MMP)14 and MYC, were examined by RT-qPCR analysis (Fig. 5B). Following treatment for $48 \mathrm{~h}$, the expression of MYC was significantly decreased by Rau treatment, which is consistent with Wnt/ $\beta$-catenin signaling pathway inhibition. Studies have shown that the stem cell-related gene Nanog has the ability to induce $\beta$-catenin phosphorylation and enhances its degradation (38). Therefore, the present study examined the expression of Nanog by western blot analysis. Nanog was increased following $24 \mathrm{~h}$ of Rau treatment, and was then decreased following $48 \mathrm{~h}$ of Rau treatment (Fig. 5C). It was hypothesized that the increase in Nanog at the earlier time point enhanced $\beta$-catenin degradation and therefore suppressed nuclear levels of $\beta$-catenin. The suppressed $\beta$-catenin levels subsequently 

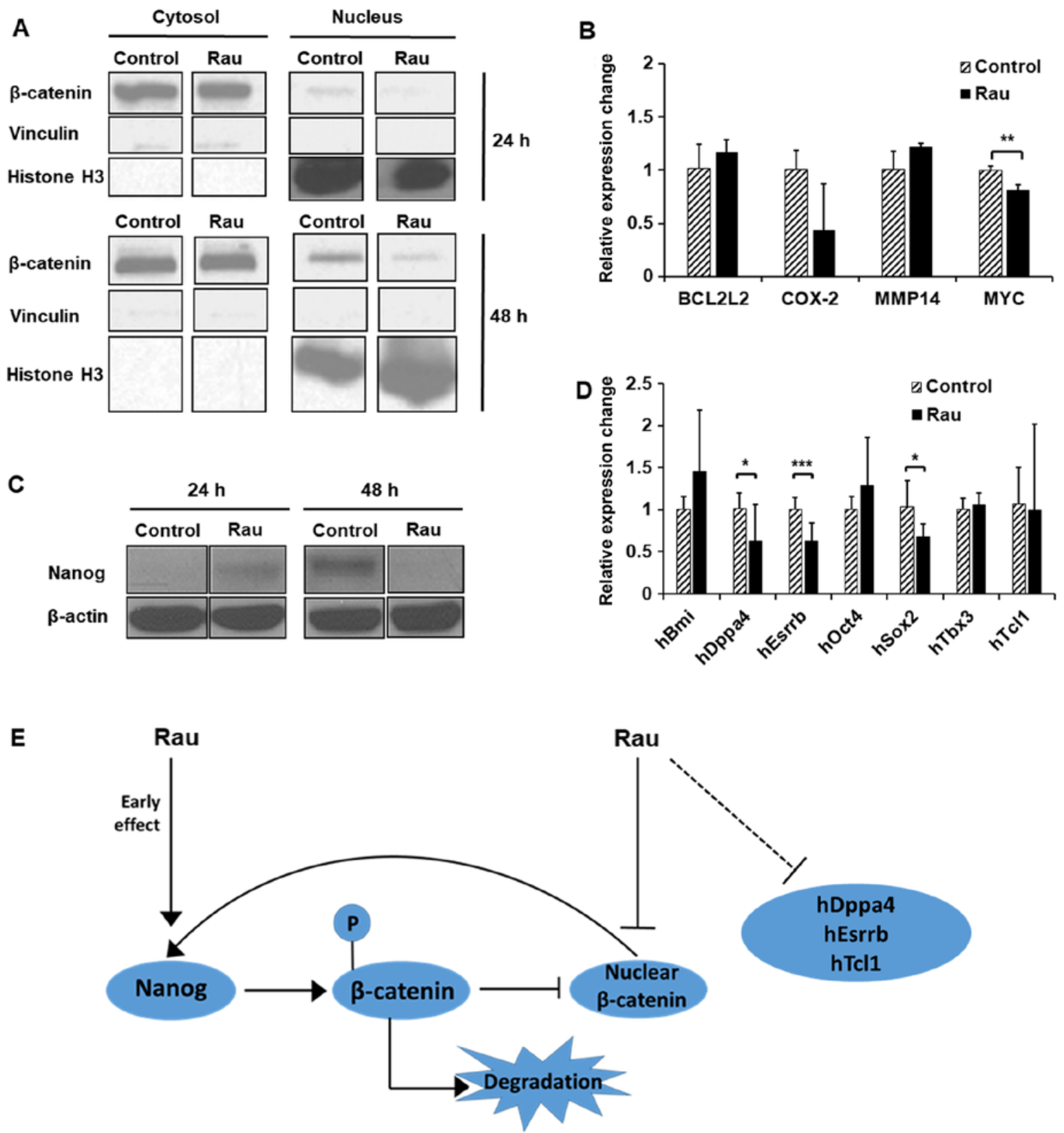

Figure 5. Decrease of nuclear $\beta$-catenin by Rau. PANC-1 cells were treated with Rau at $100 \mu \mathrm{g} / \mathrm{ml}$ for 24 and $48 \mathrm{~h}$. (A) Expression of $\beta$-catenin was detected by western blot analysis in cytoplasmic and nuclear fractions. Vinculin was a loading control for cytoplasmic proteins, and histone $\mathrm{H} 3$ was a loading control indicative for the nuclear fraction. (B) Expression of $\beta$-catenin downstream target genes at $48 \mathrm{~h}$ of Rau treatment, detected by RT-qPCR analysis. (C) Expression of Nanog was detected by western blot analysis. (D) Expression of CSC-related genes following $48 \mathrm{~h}$ of Rau treatment, detected by RT-qPCR analysis. (E) Suggested mechanism of Rau inhibiting Nanog and nuclear $\beta$-catenin. Rau treatment has an early effect in increasing the expression of Nanog, which leads to the phosphorylation and degradation of $\beta$-catenin, which represses nuclear $\beta$-catenin. The decreasing level of nuclear $\beta$-catenin negatively influenced the expression of Nanog. Rau treatment also appeared to directly inhibit $\beta$-catenin nuclear accumulation. Both can result in overall suppression of levels of Nanog and nuclear $\beta$-catenin. Rau also inhibited the RNA level of CSC-related genes, including Dppa4 and Esrrb. ${ }^{*} \mathrm{P}<0.05 ;{ }^{* *} \mathrm{P}<0.01 ;{ }^{* * *} \mathrm{P}<0.001$, compared with the untreated control group. Rau, Rauwolfia vomitoria; RT-qPCR, reverse transcription-quantitative polymerase chain reaction; BCL2L2, B-cell lymphoma 2-like 2, COX-2, cyclooxygenase-2, MMP14, matrix metalloproteinase 14; Dppa4, developmental pluripotency associated 4, Esrrb, estrogen related receptor $\beta$; Oct4, octamer-binding transcription factor 4; Tbx3, T-box 3; Tc11, T cell leukemia 1.

resulted in inhibition of the expression of Nanog at a later timepoint $(39,40)$. As a result, the Nanog and Wnt signaling pathway was suppressed by Rau.

A panel of other CSC-related genes were also examined by RT-qPCR analysis (31). Data showed that the expression levels of developmental pluripotency associated 4 (Dppa4), estrogen related receptor $\beta$ (Esrrb) and SRY-box 2 (Sox2) were inhibited following $48 \mathrm{~h}$ of Rau treatment (Fig. 5D).
Taken together, Rau treatment had an early effect in increasing the expression of Nanog, which led to the phosphorylation and degradation of $\beta$-catenin, and repressed the nuclear level of $\beta$-catenin. The decreasing level of nuclear $\beta$-catenin negatively affected the expression of Nanog. Rau treatment also appeared to directly inhibit the nuclear accumulation of $\beta$-catenin and other CSC-related genes, including MYC, resulting in the overall suppression of Nanog and nuclear 
A

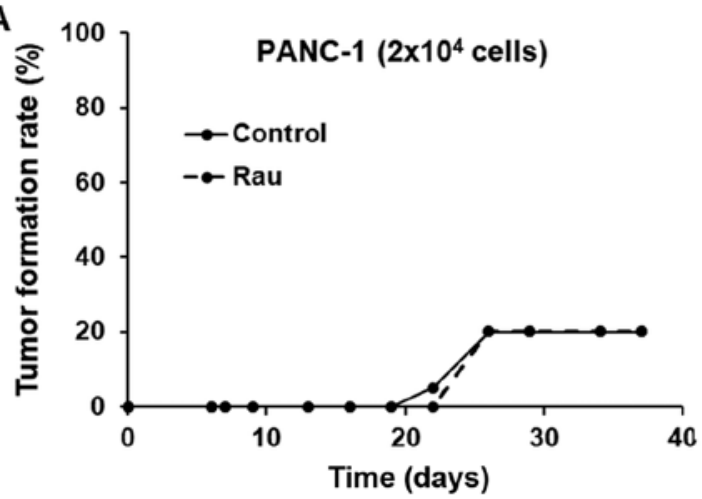

C

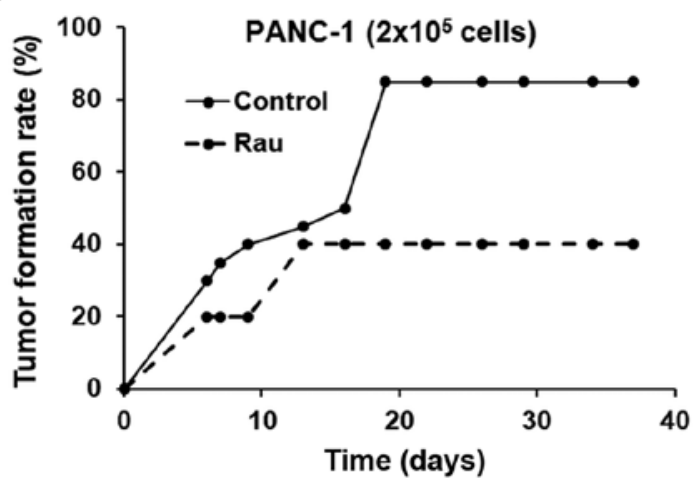

$\mathbf{E}$

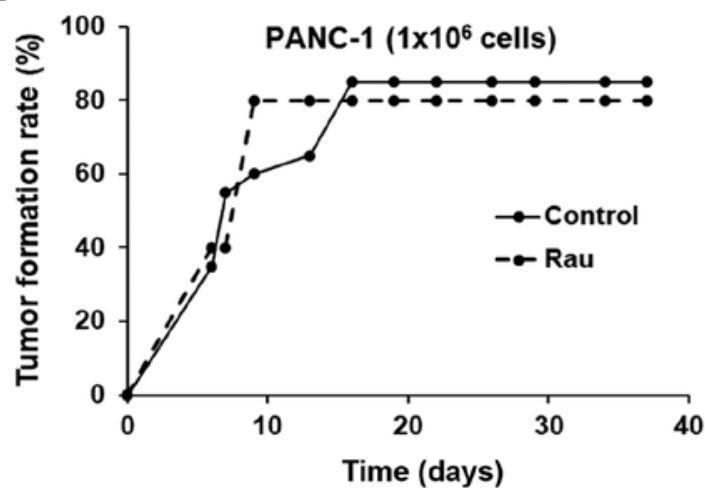

B

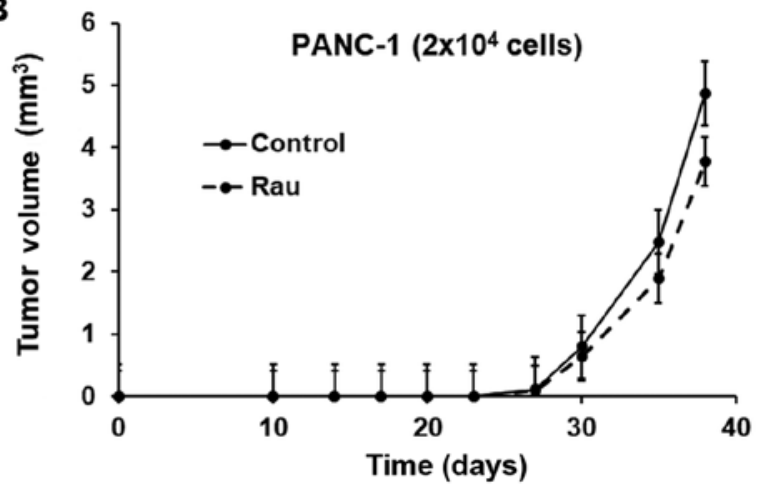

D

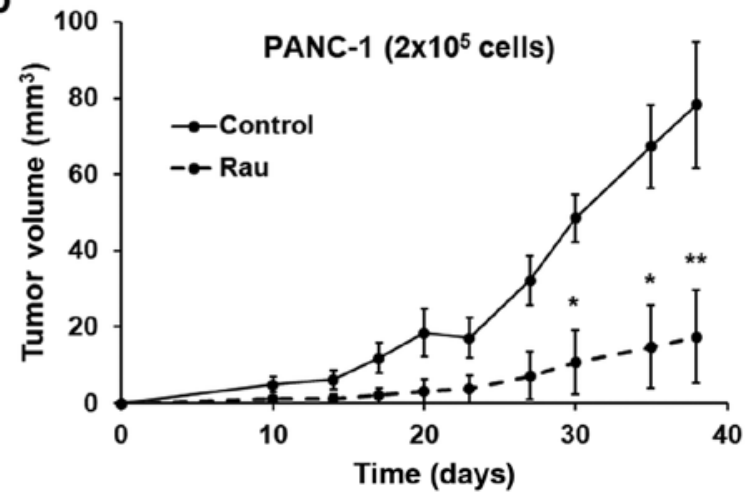

$\mathbf{F}$

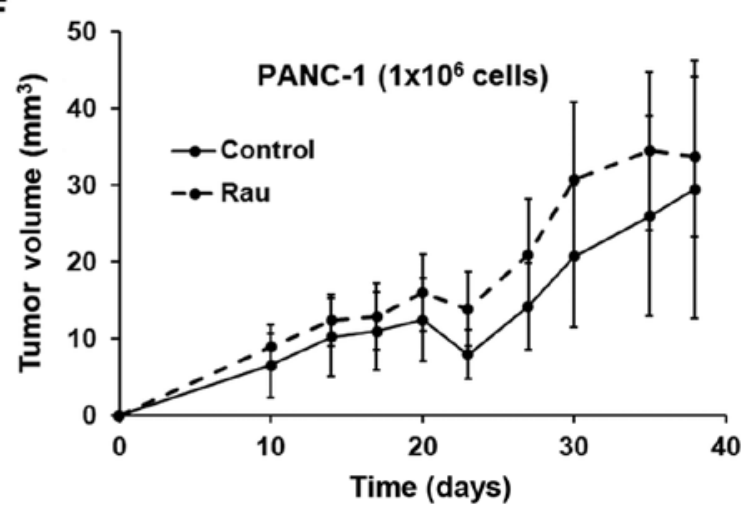

Figure 6. Effects of single Rau treatment on PANC-1 tumor formation in nude mice. (A) Tumor formation rate and (B) tumor size at $2 \times 10^{4}$ PANC-1 cells; (C) Tumor formation rate and (D) tumor size at $2 \times 10^{5}$ PANC-1 cells; (E) Tumor formation rate and (F) tumor size at 1x10 ${ }^{6}$ PANC-1 cells. PANC-1 cells were mixed with $200 \mathrm{mg} / \mathrm{ml} \mathrm{Rau}$, and then inoculated into the left flank of each mouse. The same density of PANC-1 cells were mixed with PBS, and inoculated into the right flank of each mouse. A total of 10 mice were used for each cell number. The tumor formation rate was determined as: Number of tumors observed on a specific day $/ 10 \times 100 \%$. Tumor size was monitored weekly using calipers and tumor volume was calculated using the following formula: Tumor volume $=$ width $\mathrm{x}$ width $\mathrm{x}$ length/2. ${ }^{*} \mathrm{P}<0.05 ;{ }^{* *} \mathrm{P}<0.01$. Rau, Rauwolfia vomitoria.

$\beta$-catenin (Fig. 5E). The full mechanism of Rau-induced CSC inhibition warrants further investigation.

Inhibition of pancreatic cancer stem cells in vivo. The inhibitory effects of Rau against pancreatic CSCs were examined in vivo by tumorigenicity in immunocompromised mice. Single treatment was performed first using inoculation of different numbers of PANC-1 cells at limited dilutions. The cells $\left(2 \times 10^{4}, 2 \times 10^{5}\right.$ and $\left.1 \times 10^{6}\right)$ were mixed with $200 \mathrm{mg} / \mathrm{ml}$ Rau and injected subcutaneously into the left flanks of nude mice $(n=10)$, respectively. For the control, the same number of cells were mixed with PBS and inoculated into the right flanks of the same mouse. The results are shown in Fig. 6A-F. At the lowest inoculation number $\left(2 \times 10^{4}\right.$ cells $)$, the tumor formation rate was low and no difference was observed between the treated and untreated groups. At the highest inoculation number $\left(1 \times 10^{6}\right.$ cells per injection), the untreated group reached a maximum of $90 \%$ tumor formation and the treated group reached $80 \%$, with no significant difference between the two. There was also no difference in the growth of the formed tumors between the treated and untreated groups. At $2 \times 10^{5}$ cells per injection, the single Rau treatment significantly inhibited the tumor formation rate. The growth of the formed tumors was also inhibited.

As single Rau treatment showed limited effect on the inhibition of tumor formation rate and tumor size, repeated 
A

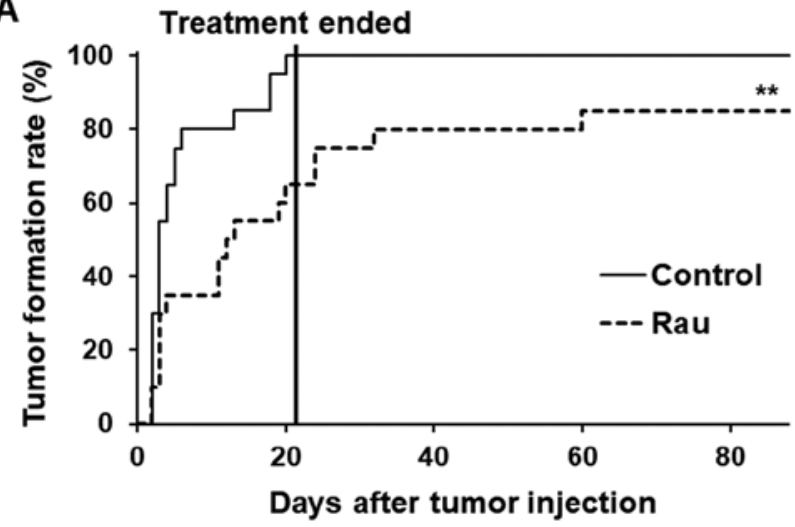

B

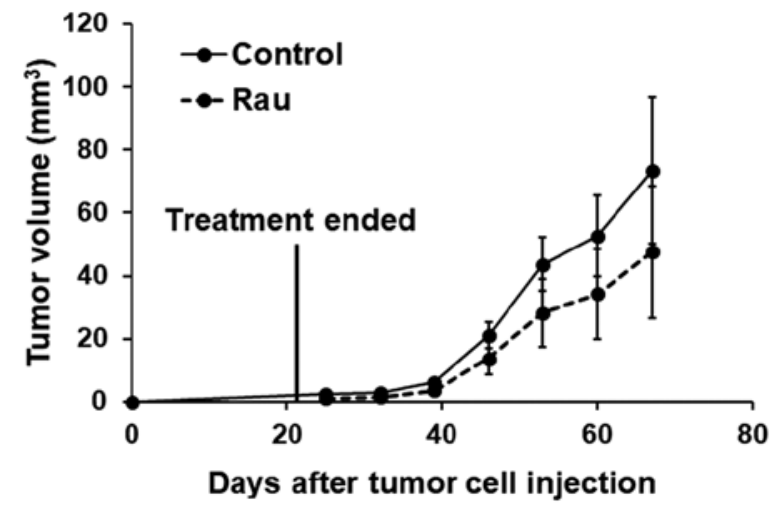

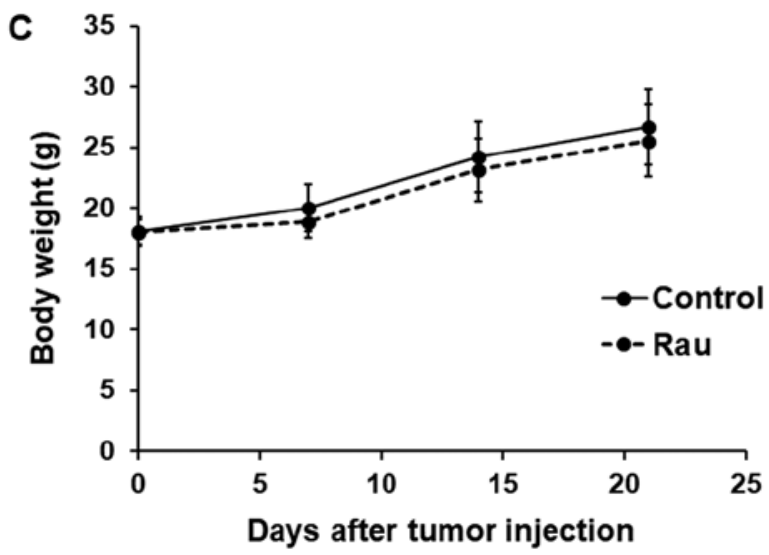

Figure 7. Effects of repeated Rau treatment on PANC-1 tumor formation and tumor growth in nude mice. (A) Tumor formation rate. $2 x 105$ PANC-1 cells were mixed with $200 \mathrm{mg} / \mathrm{ml}$ Rau or PBS (control), and inoculated at both flanks of nude mice (n=10 for each group). Treatment started the next day and lasted for 3 weeks with oral gavage of $20 \mathrm{mg} / \mathrm{kg}$ Rau or saline (control) five times per week. ${ }^{* *} \mathrm{P}<0.01$ by log-rank test. (B) Longitudinal tumor growth. Tumor size was measured weekly using calipers. Tumor volume = width $\mathrm{x}$ width $\mathrm{x}$ length/2. (C) Body weight of mice during treatment for 3 weeks. Rau, Rauwolfia vomitoria

treatment was performed with oral administration of Rau. The optimal cell number for injection was selected as $2 \times 10^{5}$ per injection. The mice $(n=10)$ were injected subcutaneously in the left and right flanks with PANC-1 cells mixed with $200 \mathrm{mg} / \mathrm{ml}$ of Rau. Treatment started the following day and lasted for 3 weeks with oral gavage of $20 \mathrm{mg} / \mathrm{kg} \mathrm{Rau}$, five times per week. The control mice $(n=10)$ were inoculated with the same number of cells mixed with PBS, and were administered with equivalent volumes of saline.

The rate of tumor formation and time of tumor formation were significantly different between the control and treated groups (Fig. 7A). At day 6, the tumor formation rate in the control group reached $80 \%$, whereas that in the Rau-treated group was only $35 \%$. At day 20 when the treatment had stopped, all mice in the control group were bearing tumors on both flanks (100\% tumor formation), whereas the Rau-treated group only had $65 \%$ tumor formation. All mice were kept for 2 months following the end of treatment. At the end of the experiment, the Rau-treated group had a maximum of $85 \%$ tumor formation, compared with $100 \%$ tumor formation in the control group. These data indicated that Rau administration at $20 \mathrm{mg} / \mathrm{kg}$ orally eliminated CSCs in $15 \%$ of the injection sites.

The growth of the formed tumors was not significantly inhibited by Rau treatment compared with the control group, which indicated the lack of a long-term inhibitory effect on tumor growth following the end of treatment (Fig. 7B). No adverse effects were observed in either group during the treatment (Fig. 7C).

\section{Discussion}

Targeting CSCs has been an attractive strategy for developing novel treatments with the aim of eliminating the entire cancer cell population. However, targeting CSCs has been challenging. First, as CSCs are only a small population in the bulk of cancer cells, anticancer agents that have cytotoxicity to the bulk of cancer cells do not necessarily inhibit CSCs $(5,6)$. CSCs possess self-renewal ability and are able to give rise to new tumors (17). CSCs are also found to be drug resistant $(12,41)$. The mechanism by which CSCs become drug resistant remains to be fully elucidated. A partial reason is the quiescent status of CSCs in a growing tumor. Other potential mechanism are the upregulated expression of the ABCG2 transporter, which facilitates the efflux of chemotherapeutic drugs from the cytosol (41), overexpression of detoxifying enzymes, enhanced DNA repair ability, and overexpression of anti-apoptotic proteins (12). Given the roles of CSC in tumor generation, metastasis and drug resistance, the identification and development of novel drugs that can inhibit CSCs may lead to a promising outcome in the comprehensive inhibition of tumor growth, metastasis and recurrence, and overcoming drug resistance. In the present study, it was demonstrated that 
the Rau extract inhibited pancreatic CSCs in vitro and in vivo. Previously, it was reported that the same Rau extract induced the apoptosis of pancreatic cancer cells and sensitized pancreatic cancer cells to gemcitabine treatment (29). The inhibition of CSCs may be another factor contributing to Rau-induced gemcitabine sensitivity in addition to its apoptosis-inducing activity. The data suggested that Rau had preferential inhibitory effects towards pancreatic CSCs, and also inhibited the bulk of cancer cells. This may be advantageous in cancer therapy as one treatment inhibits CSC and non-CSCs. The overall inhibitory effect in non-CSC and CSCs results in the inhibition of tumor growth, whereas the inhibition in CSCs is likely also to reduce metastasis and chemotherapy resistance. Given the lack of treatment options for pancreatic cancer, the benefits of Rau in pancreatic cancer treatment warrant further investigation, particularly in combination with current chemotherapies.

Dye exclusion and CSC surface markers are used in CSC isolation and provide consistent data for the enrichment of pancreatic CSCs. However, there has not been an efficient method to definitively identify and isolated a pure pancreatic CSCs and maintain/amplify them for drug development purposes (42). Functional assays, including tumor spheroid assays and tumorigenicity in mice are commonly used (43). Due to the difficulties in obtaining and maintaining a pure CSC population (44), the isolated CSCs may lose their natural environment in the bulk population (17). In the present study, the bulk of pancreatic cancer cells were treated, in addition to a dye-excluding side population, and the CSC-specific outcomes were examined. The inhibition of CSCs was shown, and was not likely due to the general cytotoxicity of Rau to the bulk of cancer cells. The data showed that Rau had an $\mathrm{IC}_{50}$ value of $317 \mu \mathrm{g} / \mathrm{ml}$ over $48 \mathrm{~h}$ of treatment towards the bulk of PANC-1 cells, and had markedly lower $\mathrm{IC}_{50}$ values of $126.9-142.04 \mu \mathrm{g} / \mathrm{ml}$ for the reduction of $\mathrm{CD} 24^{+} \mathrm{EpCam}^{+}$cells at a shorter treatment time of 24-48 h. Furthermore, in the tumor spheroid formation assay, Rau had an $\mathrm{IC}_{50}$ value of $39.44 \mu \mathrm{g} / \mathrm{ml}$ in inhibiting the number of spheroids. These data suggested that Rau had a preferential inhibitory activity towards pancreatic CSCs.

The data obtained in the present study showed that Rau reduced protein levels of nuclear $\beta$-catenin and Nanog in PANC-1 cells, which are important in stem cell initiation and maintenance. Rau also reduced the mRNA levels of several CSC-related genes, namely Dppa4, Esrrb and Sox2. The in-depth mechanism underlying how Rau interacts with Nanog and/or the $\beta$-catenin signaling pathway requires further investigation. In addition, as plant extracts contain a complex mixture of natural compounds, it is possible that Rau also affects other molecular targets and pathways that lead to its CSC inhibitory effect.

Previous studies on extracts of Rau showed inhibitory effects on the proliferation on pancreatic, ovarian and prostate cancer $(25,29,45)$. The data from animal experiments in the present study revealed the promising effects of Rau in inhibiting tumorigenicity, at a dose and administration route that can be easily translated into clinical use. No toxic sideeffects were observed in mice at this dosage. The inhibition of tumorigenicity indicated the possible role of Rau in the prevention of cancer, in addition to data indicating a treatment role. As extracts of Rauwolfia vomitoria are consumed by the American public as a health supplement, the safety, toxicity and effects of Rau as an anticancer agent require further investigation clinically.

\section{Acknowledgements}

The authors would like to thank Dr Sitta Sittampalam at the National Center for Advancing Translational Sciences, NIH for providing MRC-5 cells. We also thank our previous Research Assistant Iman Joker at KUMC and previous Postdoctoral Fellow Jun Yu at KUMC for their exploratory work on this study.

\section{Funding}

The present study was supported by a research grant provided by the Beljanski Foundation. The Beljanski Foundation had no influence on the design, performance, data collection, data analysis or manuscript preparation of the study.

\section{Availability of data and materials}

All the original data concerning this publication is available upon request.

\section{Authors' contributions}

QC conceptualized, designed and oversaw the studies. RD participated in the study design and performed the majority of the experiments. PC performed part of the cell experiments. $\mathrm{RD}$ and PC collected the data. RD, PC and QC analyzed the data. All authors participated in manuscript preparation and all approved the manuscript and agree to be accountable for all aspects of the research in ensuring that the accuracy or integrity of any part of the work are appropriately investigated and resolved.

\section{Ethics approval and consent to participate}

All animal experiments followed a protocol approved by the Institutional Animal Care and Use Committee of the University of Kansas Medical Center.

\section{Consent for publication}

Not applicable.

\section{Competing interests}

The authors declare that they have no competing interests.

\section{References}

1. Siegel RL, Miller KD and Jemal A: Cancer statistics, 2018. CA Cancer J Clin 68: 7-30, 2018.

2. Fingerhut A, Vassiliu P, Dervenis C, Alexakis N and Leandros E: What is in a word: Pancreatoduodenectomy or pancreaticoduodenectomy? Surgery 142: 428-429, 2007.

3. Yu Y, Ramena G and Elble RC: The role of cancer stem cells in relapse of solid tumors. Front Biosci (Elite Ed) 4: 1528-1541, 2012. 
4. Hidalgo M: Pancreatic cancer. N Engl J Med 362: 1605-1617, 2010.

5. Oettle $\mathrm{H}$ and Neuhaus P: Adjuvant therapy in pancreatic cancer: A critical appraisal. Drugs 67: 2293-2310, 2007.

6. Renouf D and Moore M: Evolution of systemic therapy for advanced pancreatic cancer. Expert Rev Anticancer Ther 10: 529-540, 2010.

7. Conroy T, Gavoille C, Samalin E, Ychou M and Ducreux M: The role of the FOLFIRINOX regimen for advanced pancreatic cancer. Curr Oncol Rep 15: 182-189, 2013.

8. Faris JE, Blaszkowsky LS, McDermott S, Guimaraes AR, Szymonifka J, Huynh MA, Ferrone CR, Wargo JA, Allen JN, Dias LE, et al: FOLFIRINOX in locally advanced pancreatic cancer: The Massachusetts General Hospital Cancer Center experience. Oncologist 18: 543-548, 2013.

9. Von Hoff DD, Ervin T, Arena FP, Chiorean EG, Infante J, Moore M, Seay T, Tjulandin SA, Ma WW, Saleh MN, et al: Increased survival in pancreatic cancer with nab-paclitaxel plus gemcitabine. N Engl J Med 369: 1691-1703, 2013.

10. Vishnu P and Roy V: Safety and efficacy of nab-paclitaxel in the treatment of patients with breast cancer. Breast Cancer (Auckl) 5: 53-65, 2011.

11. Conroy T, Desseigne F, Ychou M, Bouché O, Guimbaud R, Bécouarn Y, Adenis A, Raoul JL, Gourgou-Bourgade S de la Fouchardière $\mathrm{C}$, et al; Groupe Tumeurs Digestives of Unicancer; PRODIGE Intergroup: FOLFIRINOX versus gemcitabine for metastatic pancreatic cancer. N Engl J Med 364 1817-1825, 2011.

12. Vinogradov $\mathrm{S}$ and Wei X: Cancer stem cells and drug resistance: The potential of nanomedicine. Nanomedicine (Lond) 7: 597-615, 2012.

13. Shiozawa Y, Nie B, Pienta KJ, Morgan TM and Taichman RS: Cancer stem cells and their role in metastasis. Pharmacol Ther 138: 285-293, 2013.

14. Schmied BM, Ulrich A, Matsuzaki H, Li CH and Pour PM: In vitro pancreatic carcinogenesis. Ann Oncol 10 (Suppl 4) 41-45, 1999.

15. Du Z, Qin R, Wei C, Wang M, Shi C, Tian R and Peng C: Pancreatic cancer cells resistant to chemoradiotherapy rich in 'stem-cell-like' tumor cells. Dig Dis Sci 56: 741-750, 2011.

16. Lonardo E, Cioffi M, Sancho P, Crusz S and Heeschen C: Studying pancreatic cancer stem cell characteristics for developing new treatment strategies. J Vis Exp 100: e52801, 2015.

17. Reya T, Morrison SJ, Clarke MF and Weissman IL: Stem cells, cancer, and cancer stem cells. Nature 414: 105-111, 2001.

18. Ajani JA, Song S, Hochster HS and Steinberg IB: Cancer stem cells: The promise and the potential. Semin Oncol 42 (Suppl 1): S3-S17, 2015.

19. La Barre J: Hypotensive effects of the completely dereserpinised extract of Rauwolfia vomitoria. Arzneimittelforschung 23 600-605, 1973

20. Gbolade A: Ethnobotanical study of plants used in treating hypertension in Edo State of Nigeria. J Ethnopharmacol 144 $1-10,2012$.

21. Pesewu GA, Cutler RR and Humber DP: Antibacterial activity of plants used in traditional medicines of Ghana with particular reference to MRSA. J Ethnopharmacol 116: 102-111, 2008.

22. Kweifio-Okai G: Antiinflammatory activity of a Ghanaian antiarthritic herbal preparation: I. J Ethnopharmacol 33: 263-267, 1991.

23. La Barre $\mathbf{J}$ and Castiau J: Effect of reserpine-free Rauwolfia vomitoria extract on gastric motility in dogs. C R Seances Soc Biol Fil 151: 2222-2224, 1957 (In French).

24. Isaiah AM, Olawale O, Effiong EE, Idongesit NJ, Fidelis UA and Friday UU: Vitamin e supplementation with Rauwolfia vomitoria root bark extract improves hematological indices. N Am J Med Sci 4: 86-89, 2012

25. Bemis DL, Capodice JL, Gorroochurn P, Katz AE and Buttyan R: Anti-prostate cancer activity of a beta-carboline alkaloid enriched extract from Rauwolfia vomitoria. Int J Oncol 29: 1065-1073, 2006.

26. Iwu MM and Court WE: Root alkaloids of Rauwolfia vomitoria afz. Planta Med 32: 88-99, 1977.
27. Beljanski M and Beljanski MS: Three alkaloids as selective destroyers of cancer cells in mice. Synergy with classic anticancer drugs. Oncology 43: 198-203, 1986.

28. Chen Q, Chao R, Chen H, Hou X, Yan H, Zhou S, Peng W and $\mathrm{Xu}$ A: Antitumor and neurotoxic effects of novel harmine derivatives and structure-activity relationship analysis. Int $\mathbf{J}$ Cancer 114: 675-682, 2005.

29. Yu J and Chen Q: Antitumor activities of Rauwolfia vomitoria extract and potentiation of gemcitabine effects against pancreatic cancer. Integr Cancer Ther 13: 217-225, 2014

30. Livak KJ and Schmittgen TD: Analysis of relative gene expression data using real-time quantitative PCR and the 2(-Delta Delta C(T)). Methods 25: 402-408, 2001.

31. Amini S, Fathi F, Mobalegi J, Sofimajidpour H and Ghadimi T: The expressions of stem cell markers: Oct4, Nanog, Sox 2, nucleostemin, Bmi, Zfx, Tcl1, Tbx3, Dppa4, and Esrrb in bladder, colon, and prostate cancer, and certain cancer cell lines. Anat Cell Biol 47: 1-11, 2014

32. Vermeulen L, Todaro M, de Sousa Mello F, Sprick MR, Kemper K, Perez Alea M, Richel DJ, Stassi G and Medema JP: Single-cell cloning of colon cancer stem cells reveals a multilineage differentiation capacity. Proc Natl Acad Sci USA 105: 13427-13432, 2008.

33. Kim SY, Hong SH, Basse PH, Wu C, Bartlett DL, Kwon YT and Lee YJ: Cancer stem cells protect non-stem cells from anoikis: Bystander effects. J Cell Biochem 117: 2289-2301, 2016.

34. Goodell MA, McKinney-Freeman S and Camargo FD: Isolation and characterization of side population cells. Methods Mol Biol 290: 343-352, 2005

35. Richard V, Nair MG, Santhosh Kumar TR and Pillai MR: Side population cells as prototype of chemoresistant, tumor-initiating cells. BioMed Res Int 2013: 517237, 2013.

36. Takebe N, Harris PJ, Warren RQ and Ivy SP: Targeting cancer stem cells by inhibiting Wnt, Notch, and Hedgehog pathways. Nat Rev Clin Oncol 8: 97-106, 2011.

37. MacDonald BT, Tamai $\mathrm{K}$ and $\mathrm{He} \mathrm{X}$ : Wnt//-catenin signaling: Components, mechanisms, and diseases. Dev Cell 17: 9-26, 2009.

38. Cheng P, Sun X, Yin D, Xu F, Yang K, Qin L, Dong Y, Guo F, Chen A, Zhang W, et al: Nanog down-regulates the Wnt signaling pathway via $\beta$-catenin phosphorylation during epidermal stem cell proliferation and differentiation. Cell Biosci 5: 5, 2015.

39. Yong X, Tang B, Xiao YF, Xie R, Qin Y, Luo G, Hu CJ, Dong H and Yang SM: Helicobacter pylori upregulates Nanog and Oct4 via Wnt/ $\beta$-catenin signaling pathway to promote cancer stem cell-like properties in human gastric cancer. Cancer Lett 374: 292-303, 2016.

40. Takao Y, Yokota T and Koide H: Beta-catenin up-regulates Nanog expression through interaction with Oct-3/4 in embryonic stem cells. Biochem Biophys Res Commun 353: 699-705, 2007.

41. An Y and Ongkeko WM: ABCG2: The key to chemoresistance in cancer stem cells? Expert Opin Drug Metab Toxicol 5: 15291542,2009

42. Li C, Lee CJ and Simeone DM: Identification of human pancreatic cancer stem cells. Methods Mol Biol 568: 161-173, 2009.

43. Salmaggi A, Boiardi A, Gelati M, Russo A, Calatozzolo C, Ciusani E, Sciacca FL, Ottolina A, Parati EA, La Porta C, et al: Glioblastoma-derived tumorospheres identify a population of tumor stem-like cells with angiogenic potential and enhanced multidrug resistance phenotype. Glia 54: 850-860, 2006.

44. Nagare RP, Sneha S, Priya SK and Ganesan TS: Cancer stem cells - Are surface markers alone sufficient? Curr Stem Cell Res Ther 12: 37-44, 2017.

45. Yu J, Ma Y, Drisko J and Chen Q: Antitumor activities of Rauwolfia vomitoria extract and potentiation of carboplatin effects against ovarian cancer. Curr Ther Res Clin Exp 75: 8-14, 2013.

This work is licensed under a Creative Common Attribution-NonCommercial-NoDerivatives 4.0 International (CC BY-NC-ND 4.0) License. 